\title{
STRATEGI GURU DALAM PENERAPAN PEMBELAJARAN KONTEKSTUL ABAD 21 DI MA DDI TAKKALASI
}

\author{
Nur Rifiatul Azisah ${ }^{1}$, Muhammad Syukur ${ }^{2}$ \\ ${ }^{1,2}$ Program Studi Pendidikan Sosiologi, Fakultas Ilmu Sosial, Universitas Negeri Makassar \\ nurrifiatulazisah@gmail.com ${ }^{1}$, m.syukur@unm.ac.id ${ }^{2}$
}

\begin{abstract}
ABSTRAK
Penelitian ini bertujuan untuk mendiskripsikan Strategi Penerapan Pembelajaran Kontekstual Abad 21 di MA DDI Takkalasi. Jenis penelitian ini adalah kualitatif dengan pendekatan deskriptif. Jumlah Informan sebanyak 11 orang yang dipilih dengan teknik purposive sampling. Teknik pengumpulan data dengan metode observasi, wawancara, dan dokumentasi. Pengecekan keabsahan data menggunakan teknik member check. Teknik analisis data meliputi reduksi data, penyajian data dan penarikan kesimpulan. Hasil penelitian menunjukkan bahwa: Adapun hasil dari penelitian ini menunjukkan bahwa (1) Penerapan pembelajaran kontekstual abad 21 di MA DDI Takkalasi Kabupaten Barru telah terlihat pada indikator penerapkan ketujuh komponen yang melandasi pelaksanaan pembelajaran kontekstual yakni konstruktivisme, inkuiri, bertanya (questioning), masyarakat belajar (learning community), pemodelan (modeling), refleksi (feflection), dan penilaian nyata (authentic assessment). (2). Faktor yang menghambat guru dalam proses pembelajaran kontekstual itu yakni berasal dari siswa sendiri kemudian pada sarana dan prasaran yang kurang memadai di sekolah yang mengakibatkan proses pembelajaran terkendala.
\end{abstract}

Kata kunci : Pembelajaran Kontekstual, Strategi Guru

\begin{abstract}
This study aims to describe the 21st Century Contextual Learning Application Strategy at MA DDI Takkalasi. This type of research is qualitative with a descriptive approach. The number of informants as many as 11 people who were selected by purposive sampling technique. Data collection techniques using observation, interview, and documentation methods. Checking the validity of the data using the member check technique. Data analysis techniques include data reduction, data presentation and drawing conclusions. The results show that: The results of this study indicate that (1) The application of 21st century contextual learning at MA DDI Takkalasi Barru Regency has been seen in the indicators of implementing the seven components that underlie the implementation of contextual learning, namely constructivism, inquiry, questioning, the learning community, modeling, reflection, and authentic assessment. (2). The factor that hinders the teacher in the contextual learning process is that it comes from the students themselves and the inadequate facilities and infrastructure at school which results in the learning process being constrained.
\end{abstract}

Keywords: Contextual Learning, Teacher Strategy

\section{PENDAHULUAN}

Perkembangan ilmu pengetahuan, teknologi dan kehidupan pada abad 21 inibegitu cepat dan menimbulkan perubahan pada berbagai bidang kehidupan. Di Indonesia, perkembangan IPTEK telah merubah berbagai aspek kehidupan bangsa Indonesia. Salah satu masalah pokok yang dihadapi oleh bangsa Indonesia adalah upaya peningkatan mutu pendidikan, baik mutu dari jenjang sekolah dasar sampai pada jenjang perguruan tinggi. Menyikapi hal tersebut maka perlu dipersiapkan kualitas sumber daya manusia yang baik. Hal ini dimaksudkan agar masyarakat tidak tertinggal, mampu bersaing di era global dan mampu mengikuti pesatnya perkembangan zaman.

(Arifin, 2014) pendidikan merupakan hal yang sangat penting dalam kehidupan dan berperan dalam meningkatkan kualitas sumber daya manusia. Pendidikan dapat ditempuh melalui lembaga informal maupun formal. Sekolah merupakan jalur pendidikan formal 
yang berfungsi sebagai tempat individu dalam meningkatkan pengetahuan, dan paling mudah untuk membina generasi muda yang diaksanakan oleh pemerintah maupun masyarakat.

Usaha untuk meningkatkan mutu pendidikan di Indonesia dapat dilihat dengan adanya peningkatan sarana dan prasarana pendidikan, profesionalisme tenaga pendidik, maupun peningkatan mutu anak didik. Sedangkan untuk mencetak peserta didik yang mempunyai mutu tinggi maka diperlukan adanya sarana yang berupa lembaga yang melaksanakan pendidikan formal atau yang lebih dikenal dengan pendidikan sekolah (Humairah \& Awaru, 2017).

Piaget menekankan pentingnya kegiatan seorang siswa yang aktif dalam mengkontruksi pengetahuan. Dengan keaktifannya mengolah bahan, bertanya secara aktif, dan mencerna bahan dengan kritis, siswa akan dapat menguasai bahan dengan baik (Demetriou et al., 2016). Pada abad 21 terjadi perubahan strategi pengajaran yang dilakukan oleh guru dari cara yang tradisional kini mengarah pada pendekatan digital yang dirasa lebih relevan dalam memenuhi kebutuhan siswa. Akan tetapi proses transisi dari lingkungan kelas yang menerapkan cara tradisional ke cara digital sangat bervariasi tergantung pada cara guru dan sekolah yang bersangkutan dalam merespon dan menyikapinya.

Guru sangat berperan dalam membantu perkembangan peserta didik untuk mewujudkan tujuan hidupnya secara optimal. Minat, bakat, kemampuan, dan potensi yang dimiliki peserta didik tidak akan dapat berkembang secara optimal tanpa bantuan dari seorang guru (Arni \& Awaru, 2018). Guru diharapkan memperhatikan peserta didik secara optimal. Itulah sebabnya, guru selain memperhatikan peserta didik secara kelompok juga diharapkan pula memperhatikan peserta didik secara individual. Oleh karena itu, pendidikan harus dirancang sedemikian rupa dan memungkinkan para peserta didik dapat mengembangkan potensi yang dimiliki secara alami, kreatif dalam suasana kebebasan, kebersamaan, dan tanggung jawab. Selain itu, pendidikan harus dapat menghasilkan lulusan yang bisa memahami masyarakatnya dengan segala faktor yang dapat mendukung kehidupan mereka di masyarakat.

Para guru dalam melaksanakan pembelajaran memerlukan kesiapan secara profesional agar tujuan pembelajaran dapat dicapai dengan maksimal. Salah satu bentuk kesiapan guru sebelum melaksanakan pembelajaran di kelas adalah menyusun rancangan pembelajaran yang relevan dengan perkembangan zaman dan kebutuhan peserta didik.

Rancangan pembelajaran yang harus disiapkan mencakup tiga hal pokok yaitu meliputi tujuan pembelajaran, inti materi pembelajaran, dan evaluasi pembelajaran. Guru dalam menyusun tujuan pembelajaran berdasarkan pada kurikulum dengan mengembangkan KI dan KD dan disesuaikan dengan lingkungan sosial siswa dalam kehidupan sehari-hari. Inti pembelajaran dikembangkan disesuaikan dengan tujuan pembelajaran yang ingin dicapai berdasarkan pada kurikulum yang digunakan. Sementara evaluasi disusun untuk melihat keberhasilan pembelajaran yang telah dilaksanakan serta melakukan umpan balik refleksi kegiatan pembelajaran yang telah dilakukan (Fitrianti, 2018).

Strategi pembelajaran yang bertujuan membantu siswa dalam menghubungkan teori dan implementasinya dalam kehidupan sehari-hari merupakan sesuatu yang perlu dikembangkan di dunia pendidikan, khususnya di Indonesia. Faktanya siswa-siswa sekarang tiba di sekolah tanpa persiapan melakukan pembelajaran. Biasanya, mereka dibatasi oleh pemahaman materi yang akan disampaikan sehingga mereka tidak mampu memahami materi yang lebih rumit maupun menemukan hal-hal yang tersembunyi. 
Mereka seringkali tidak mempunyai kerangka berpikir dalam memahami logika dari suatu pendapat tertulis. Hal ini merupakan akibat dari keterbatasan pendidikan tradisional yaitu biasanya siswa hanya menghabiskan waktu untuk mendengarkan pengajaran dan menyelesaikan latihan-latihan yang membosankan dan akhirnya mereka mengikuti ujian yang hanya bisa mengungkapkan pemahaman siswa dan mengukur kemampuan siswa menghafalkan fakta tanpa mereka tahu bahwa sebenarnya bertanya, diskusi, mencari tahu, berpikir kritis atau terlibat dalam proyek kerja nyata dan pemecahan masalah adalah hal yang penting dari suatu proses pembelajaran.

Pembelajaran kontekstual merupakan salah satu pembelajaran abad 21 yang mengarahkan siswa kepada upaya untuk membangun kemampuan berpikir dan kemampuan menguasai materi pembelajaran. Pengetahuan yang sumbernya dari luar diri dikonstruksi dalam diri siswa (Harianto et al., 2020). Dalam hal ini pengetahuan tidak diperoleh dengan cara diberikan atau ditransfer dari orang lain melainkan dibentuk dan konstruksi oleh siswa sendiri, sehingga bisa mengembangkan intelektualnya. Dalam proses pembelajaran guru harus memahami hakikat materi pelajaran yang diajarkan sebaga suatu pelajaran yang dapat mengembangkan kemampuan berpikir siswa dan memahami berbagai model pembelajaran yang dapat merangsang kemampuan siswa untuk belajar dengan perencanaan pengajaran yang matang oleh guru.

Dari konsep pembelajaran kontekstual yang telah dijelaskan diatas yakni dapat disimpulkan bahwa pembelajaran kontekstual adalah konsep pembelajaran yang membantu pendidik mengaitkan setiap materi yang dipelajari oleh siswa dengan kehidupan sehari-hari atau bidang-bidang tertentu, sehingga siswa dapat merasakan makna dari setiap materi pelajaran yang diterimanya dan mengimplementasikannya dalam berbagai aspek kehidupan. Peserta didik memperoleh ketrampilan dari konteks yang terbatas sedikit demi sedikit, dan dari proses mengkonstruksi sendiri, sehingga belajar akan bermakna.

\section{METODE PENELITIAN}

Jenis penelitian ini adalah kualitatif dengan pendekatan deskriptif. Dalam penelitian ini mengambil lokasi di MA DDI Takkalasi Kelurahan Takkalasi, Kecamatan Balusu, Kabupaten Barru. Provinsi Sulawesi Selatan. Adapun tahap-tahap penelitian yang dilakukan dalam penelitian ini secara garis besar yaitu tahap pra-penelitian, tahap penelitian, dan tahap akhir. Sumber data yang digunakan yaitu sumber data primer dan sumber data sekunder. Jumlah informan sebanyak 11 orang yang dipilih berdasarkan teknik purposive sampling. Teknik pengumpulan data dengan metode observasi, wawancara, dan dokumentasi. Pengecekan keabsahan data menggunakan teknik member check. Teknik analisis data meliputi reduksi data, penyajian data dan penarikan kesimpulan (Miles et al., 2014), (Upe, 2016).

\section{HASIL PENELITIAN DAN PEMBAHASAN}

\section{Strategi Guru Dalam Penerapan Pembelajaran Kontekstual Abad 21.}

Pembelajaran kontekstual merupakan suatu konsep belajar dimana guru menghadirkan situasi nyata kedalam kelas dan mendorong siswa membuat hubungan antara pengetahuan yang dimilikinya dengan penerapannya dalam kehidupan mereka sebagai anggota keluarga dan masyarakat. Dengan konsep itu, hasil pembelajaran agar lebih bermakna bagi siswa. Proses pembelajaran berlangsung alamiah dalam bentuk kegiatan siswa bekerja dan mengalami, bukan transfer pengetahuan dari guru ke siswa. Pendekatan kontekstual adalah salah satu pendekatan pembelajaran yang menekankan 
pentingnya lingkungan alamiah itu diciptakan dalam proses belajar agar kelas lebih "hidup" dan "bermakna" karena siswa "mengalami" sendiri apa yang dipelajari (Hajariani, 2017).

Bila kontekstual diterapkan dengan benar, siswa akan terlatih untuk dapat menghubungkan apa yang diperolehnya dikelas dengan kehidupan dunia nyata yang ada di lingkungan. Untuk itu guru perlu memahami konsep model pembelajaran kontekstual terlebih dahulu dan dapat menerapkannya dengan benar. Agar siswa dapat belajar lebih efektif, guru perlu mendapat informasi tentang konsep-konsep pembelajaran kontekstual dan penerapannya.

Tugas guru dalam kelas kontekstual adalah membantu siswa mencapai tujuannya. Maksudnya guru lebih banyak berurusan dengan strategi daripada memberikan informasi. Tugas guru dalam mengelolah kelas sebagai sebuah tim yang bekerja bersama untuk menemukan sesuatu yang baru bagi siswa. Sesuatu yang baru atang dari menemukan sendiri bukan dari apa kata guru. Dalam pembelajaran kontekstual guru bukan lagi seseorang yang paling tahu, guru layaknya mendengarkan siswa-siswanya, mendampingi siswa dalam mencapai kompetensi dasar.

Jhonson menguraikan bahwa pembelajaran kontekstual adalah sebuah sistem yang merangsang otak untuk menyususn pola-pola yang mewujudkan makna.Lebih lanjut lagi, Elaine mengatakan bahwa pembelajaran kontekstual adalah suatu sistem pembelajaran yang cocok dengan otak yang menghasilkan makna dengan menghubungkan muatan akademis dengan konteks dari kehidupan sehari-hari siswa berada (Yahya, 2019). Riyanto mengungkapkan bahwa pembelajaran kontekstual merupakan suatu konsep belajar dimana guru menghadirkan situasi dunia nyata ke dalam kelas dan mendorong siswa membuat hubungan antara pengetahuan yang dimilikinya dengan penerapannya dalam kehidupan mereka sebagai anggota keluarga dan masyarakat (Wibowo, 2018).

Berdasarkan hasil penelitian yang dilakukan, dapat diketahui bahwa guru ilmu-ilmu sosial di MA DDI Takkalasi guru tidak lagi hanya menggunakan metode ceramah, akan tetapi guru sudah berusaha menggunakan metode yang bervariasi agar jalannya pembelajaran menarik dan tidak membosankan. Guru dengan siswa sebagai pelaku pendidikan, diharapkan dapat melakukan kerjasama guna menciptakan inovasi pembelajaran dalam mengembangkan kegiatan belajar mengajar di sekolah dengan tujuan untuk menghindari rasa bosan dan jenuh supaya kegiatan belajar mengajar bisa berjalan dengan efektif dan efesien.

Pembelajaran kontekstual yang berorientasi untuk membangun pengetahuan siswa secara mandiri berdasarkan data wawancara dan observasi yang dilakukan peneliti pembelajaran kontekstual ada 7 komponen yang dikaitkan guru dalam pelaksanaan pembelajaran yang meliputi konstruktivisme (Constructivism), bertanya (Questioning), menemukan (inquiri), masyarakat belajar (Learning Comunity), pemodelan (modeling), refleksi (Reflection), dan penilaian sebenarnya (Authentic Assesment)dan menghubungkanya pada pembelajaran abad 21 (Berfikir Kritis, Kreativitas, Komunikasi, dan Kolaborasi) (Erika, 2020).

Konstruktivisme merupakan landasan pendekatan kontekstual. Pengetahuan dibangun oleh manusia sedikit demi sedikit, yang hasilnya diperluas melalui konteks yang terbatas, dalam konstruktivisme strategi lebih diutamakan dibanding seberapa banyak peserta didik memperoleh dan mengingat pengetahuan. Dari hasil wawancara guru menerapkan konstruktivisme dengan cara guru menekankan bahwa belajar tidak hanya sekedar menghafal dan mengingat pengetahuan saja, tetapi merupakan suatu proses belajar mengajar dimana siswa juga aktif. Guru meminta siswa untuk berfikir dan mengeluarkan 
pendapatnya dari pengetahuan yang sedikit-sedikit siswa temukan. Contohnya dalam materi tentang manusia sebagai makhluk sosial, bisa tanyakan ke anak-anak apa itu makhluk sosial yang bisa mereka ambil dari kehidupan mereka sehari-hari. Dari pemikiran anak-anak akan dikembangkan sedikit demi sedikit. Jadi di kontruktivisme ini sendiri tidak hanya sekedar ceramah memberikan materi, tetapi juga mengajak anak-anak untuk berfikir dan mengeluarkan ide ataupun pemikiran yang ada pada siswa.

Selanjutnya Inkuiri atau menemukan, penerapan inkuiri dalam pembelajaran kontekstual yakni keterampilan dan pengetahuan yang diperoleh siswa diharapkan bukan hasil mengingat seperangkat fakta-fakta, tetapi hasil menemukan sendiri. Inkuiri merupakan inti dari kegiatan pembelajaran kontekstual. Kegiatan ini diawali dari pengamatan terhadap fenomena, dilanjutkan dengan kegiatan-kegiatan bermakna untuk menghasilkan temuan yang diperoleh sendiri oleh siswa. Dari hasil wawancara dilapangan strategi yang dilakukan dalam hal inkuiri yakni dengan menyuruh mereka mengamati halhal yang terjadi dalam kehidupan sehari-hari mereka, karena setiap fenomena yang terjadi itu merupakan hal yang bisa menjadi sejarah. nah dari hal tersebutlah biasanya ibu mengaitkan dengan materi pembelajaran. Dalam pembelajaran diskusi atau tanya jawab biasanya menjadi salah satu metode atau model yang saya gunakan. Setelah melakukan pengamatan siswa biasanya saya suruh berdiskusi, mengeluarkan pendapatnya, nah dengan diskusikan bisa melatih daya berfikir dan kreativitas siswa sehingga siswa dapat lebih semangat dalam belajar

Selanjutnya bertanya (questioning), Bertanya dalam pembelajaran dipandang sebagai upaya guru untuk mendorong, membimbing, dan menilai kemampuan berfikir kritis, dan kereativitas siswa dalam menerima materi yang telah disampaikan. Dalam proses belajar mengajar bertanya tidak harus dilakukan antara siwa dengan guru saja,akan tetapi bertanya dapat dilakukan diantara siswa lainnya. Bagi siswa bertanya merupakan kegiatan yang sangat penting dalam pembelajaran, karena dengan bertanya siswa dapat menggali informasi atau materi yang belum diketahuinya sedangkan bagi guru bertanya adalah upaya untuk mengetahui sejauh mana siswa dapat menangkap materi yang diajarkan. Dan dari hasil wawancara dilapangan, strategi bertanya diterapkan oleh guru hampir disetiap proses pembelajaran berlangsung. Siswa diberi kesempatan bertanya kepada guru baik sebelum maupun sesudah materi pelajaran diberikan, kegiatan bertanya juga digunakan guru sebagai apersepsi dalam pembelajaran dengan tujuan sebagai umpan balik terhadap materi yang telah diberikan.

Selanjutnya masyarakat belajar (Learning Community). Masyarakat belajar merupakan hasil pembelajaran yang diperoleh dari kerjasama dengan orang lain. Hal ini berarti bahwa hasil belajar bisa diperoleh dengan berdiskusi antar teman, antar kelompok, antara yang tahu kepada yang tidak tahu, baik di dalam maupun di luar kelas. Dari hasil wawancara dilapangan masyarakat belajar sangat berpengaruh dalam kegiatan pembelajaran hal ini dikarenakan siswa dituntut untuk mampu berkomunikasi, berkolaborasi, berfikir kritis baik dengan diskusi dalam menyelesaikan masalah mengeluarkan pendapatnya, serta kreatif dalam hal pembelajaran. Masyarakat belajar yang biasa diterapkan guru di MA DDI Takkalasi yakni dengan membentuk kelompokkelompok belajar yang terdiri dari beberapa siswa untuk mendiskusikan materi atau permasalah yang terkait dengan mata pelajaran yang diberikan oleh guru.

Selanjutnya pemodelan (Modeling). Pemodelan pada dasarnya merupakan sebuah proses pembelajaran dengan memperagakan atau menunjukan sesuatu sebagai contoh yang dapat ditiru atau dilakukan oleh siswa. Model yang dimaksud bisa berupa pemberian contoh, cara mengoperaikan sesuatu, menunjukan hasil karya, atau memperagakan suatu 
penampilan. Sanjaya (2011, h. 267) "modeling merupakan azas yang cukup penting dalam pembelajaran, sebab melalui modeling siswa dapat terhindar dari pembelajaran yang teoritis (abstrak) yang dapat memungkinkan terjadinya verbalisme". Dari hasil waancara dilapangan dikatakan bahwa pemodelan yang biasa dilakukan oleg guru yakni dengan menayangkan video-video atau gambar yang terkait dengan materi sehingga daya berfikir dan kreativitas siswa dalam menangkap materi lebih termotivasi dan proses pembelajaran menjadi menarik bagi siswa.

Selanjutnya refleksi. Refleksi dalam hal ini merupakan perenungan kembali atas pengetahuan yang baru dipelajari. Dengan memikirkan apa yang baru saja dipelajari, menelaah, dan merespon semua kejadian, aktivitas, atau pengalaman yang terjadi dalam pembelajaran, bahkan memberikan masukan atau saran jika diperlukan, siswa akan menyadari bahwa pengetahuan yang baru diperolehnya merupakan pengayaan atau bahkan revisi dari pengetahuan yang telah dimiliki sebelumnya hal ini membutuhkan daya berfiki kritis siswa umtuk mengingat kegiatan pembelajaran. Dari hasil wawancara dilapangan dikemukakan bahwa refleksi tidak hanya dilakukan diakhir pembelajaran saja akan tetapi refleksi dilakukan pula diawal pembelajaran guna mengingat kembali materi sebelumnya apalagi ketika materinya berhubungan dengan materi yang akan disampaikan.

Selanjutnya penilaian nyata (Authentic Assessment). Penilaian merupakan proses pengumpulan berbagai data yang memberikan gambaran atau informasi mengenai perkembangan belajar siswa. Pengumpulan berbagai data dalam hal ini bukan semata-mata pada hasil pembelajaran saja tapi dilakukan disepanjang proses pembelajaran siswa berlangsung, atau dengan kata lain penilaian dilakukan secara komperhensif dan seimbang antara penilaian proses dan hasil. Penilaian autentik memberikan kesempatan luas bagi siswa untuk menunjukan apa yang telah mereka pelajari selama proses belajar mengajar" (Sholihah, 2018).

Dengan menerapkan ketujuh kompenen pembelajaran kontekstual dan menghubungkanya pada pembelajaran abad 21 (Berfikir Kritis, Kreativitas, Komunikasi, dan Kolaborasi) pada saat proses pembelajaran serta menghubungkan terhadap kehidupan sehari-hari siswa agar pembelajaran lebih bermakna, berkesan, dan bervariasi, menarik sehingga tercipta pembelajaran yang menyenagkan bagi siswa maupun guru.

\section{Faktor Penghambat Guru Dalam Menerapkan Strategi Pembelajaran Kontekstual.}

Dalam pendidikan, kegiatan pembelajaran tidaklah selalu berjalan dengan baik sesuai dengan harapan kita, namun ada beberapa faktor yang dapat memengaruhi keberhasilan dalam proses pembelajaran tersebut. Dalam penelitian ini, faktor penghambat dalam penerapan pembelajanan kontekstual di MA DDI Takkalasi itu sendiri yakni berasal dari guru itu sendiri, siswa serta sarana dan prasarana yang ada di sekolah/madrasah tersebut. Hal ini dilihat dari hasil wawancara guru Ilmu-ilmu Sosial MA DDI Takkalasi.

a. Siswa dalam kelas dapat dianggap sebagai seorang individu dalam suatu masyarakat kecil yaitu kelas dan sekolah. Mereka harus tahu hak-haknya sebagai bagian dari suatu kesatuan masyarakat disamping mereka juga harus tahu akan kewajiban dan keharusan menghormati hak-hak oang lain dan teman-teman sekellasnya. Oleh karena itu diperlukan kesadaran yang tinggi dari siswa akan hak serta kewajiban dalam mengikuti kegiatan belajar mengajar.

b. Sarana dan prasarana yang merupakan faktor yang penting agar memaksimalkan proses pemeblajaran. Sarana dan prasarana yang kurang lengkap akan menjadi kendala yang berarti bagi seorang guru dalam kegiatan belajar mengajar. 
Terkait teori yang digunakan dalam penelitian ini ada dua yakni teori Struktural Fungsional Talcott Parsonsdan teori Free Discovery Learning dari BrunerPada esensinya teori Struktur Fungsional Talcott Parson bahwa apabila strategi guru dalam penerapan pembelajaran kontekstual abad 21 telah diterapkan dengan baik maka hal tersebut akan berdampak terhadap efektifnya pembelajaran sehingga pembelajaran menjadi lebih menarik dan menyenangkan. Hal tersebut seperti yang dikemukakan oleh Parson bahwa "suatu fungsi adalah suatu kompleks kegiatan-kegiatan yang diarahkan suatu kebutuhan atau kebutuhan-kebutuhan sistem itu (Syukur, 2018).

Pada Teori kedua yakni teori Free Discovery Learning dari Bruner dimana teori menjelaskan bahwa proses belajar akan berjalan dengan baik dan kreatif jika guru memberikan kesempatan kepada siswa untuk menemukan suatu konsep, teori, aturan, atau pemahaman melalui contoh-contoh yang ia jumpai dalam kehidupannya (Nurhadi, 2020). Berdasarkan teori ini sistem pembelajaran kontekstual abad 21 menjadi suatu inovasi barupada saat pembelajaran utamanya di abad 21 ini. Dalam teori iniperkembangan kognitif seseorang terjadi melalui tiga tahap yang ditentukan oleh caranya melihat lingkungan, yaitu Enaktif: seseorang melakukan aktivitas-aktivitas dalam upaya untuk memahami lingkungan sekitarnya, Ikonik: seseorang memahami objek-objek atau dunianya melalui gambar-gambar dan visualisasi verbal. Maksudnya dalam memahami dunia sekitarnya anak belajar melalui bentuk perumpamaan (tampil) dan perbandingan (komparasi), dan Simbolik: seseorang telah mampu memiliki ide-ide atau gagasan-gagasan abstrak yang sangat dipengaruhi oleh kemampunnya dalam berbahasa dan berlogika.

\section{PENUTUP}

Berdasarkan data yang telah dikumpulkan dan analisis yang telah dikakukan pada bab-bab sebelumnya tentang strategi guru dalam penerapan pembelajaran kontekstual abad 21 di MA DDI Takkalasi, maka dapat diambil suatu kesimpulan bahwa:

1. Strategi guru dalam penerapan pembelajaran kontekstual dengan abad 21 yakni idak lepas dari peran serta segenap guru yang selalu mendukung dan memperlancar aktivitas kegiatan belajar yaitu dengan menerapkan ketujuh komponen yang melandasi pelaksanaan pembelajaran kontekstual konstruktivisme, inkuiri, bertanya (questioning), masyarakat belajar (learning community), pemodelan (modeling), refleksi (feflection), dan penilaian nyata (authentic assessment). Pelaksanaan proses pembelajaran kontekstual meliputi persiapan pembelajaran, proses pembelajaran dan sistem penilaian pembelajaran dengan menghubungkan pembelajaran abad 21 (Berfikir Kritis, Kreativitas, Komunikasi, dan Kolaborasi).

2. Faktor yang menghambat guru dalam proses pembelajaran kontekstual itu berasal dari siswa itu sendiri, kemudian pada sarana dan prasaran yang kurang di sekolah yang mengakibatkan proses pembelajaran terkendala.

\section{DAFTAR PUSTAKA}

Arifin, Z. (2014). Sosiologi Pendidikan. Makassar: Anugrah Mandiri.

Arni, A., \& Awaru, A. O. T. (2018). Peranan Guru Dalam Mengatasi Kesulitan Belajar Akademik Sosiologi Siswa Kelas Xi Di SMA Negeri 12 Makassar. Jurnal sosialisasi, 29-33.

Demetriou, A., Shayer, M., \& Efklides, A. (2016). Neo-Piagetian theories of cognitive development: Implications and applications for education. Routledge. 
Erika, Y. (2020). Pengaruh Pendekatan Contextual Teaching And Learning (Ctl) Terhadap Kemampuan Komunikasi Matematis Pada Siswa Kelas Vii Mts.

Fitrianti, L. (2018). Prinsip Kontinuitas Dalam Evaluasi Proses Pembelajaran. Al-Ishlah: Jurnal Pendidikan, 10(1), 89-102.

Hajariani, A. (2017). Penerapan Model Pembelajaran Learning Start With A Question Dengan Pendekatan Kontekstual Untuk Meningkatkan Minat Dan Hasil Belajar Akuntansi Siswa Kelas X AK DI SMK 1 Swasta Daerah SEI Bejangkar TP 2016/2017. UNIMED.

Harianto, G. P., Rusijiono, R., Masitoh, S., \& Setyawan, W. H. (2020). CollaborativeCooperative Learning Model To Improve Theology Students'characters: Is It Efective? Jurnal Cakrawala Pendidikan, 39(2), 409-421.

Humairah, H., \& Awaru, A. O. T. (2017). Penggunaan Media Pembelajaran Audio Visual Dalam Meningkatkan Keaktifan Belajar Sosiologi Siswa Kelas XI IPS Di Madrasah Alyiah Buntu Barana Kabupaten Enrekang. JURNAL SOSIALISASI, 61-64.

Miles, M. B., Huberman, A. M., \& Saldana, J. (2014). Qualitative Data Analysis: A Method Sourcebook. Routledge.

Nurhadi, N. (2020). Teori Kognitivisme serta Aplikasinya dalam Pembelajaran. EDISI, 2(1), 77-95.

Sholihah, R. (2018). Penerapan model pembelajaran Contextual teaching and learning (ctl) dalam meningkatkan kemampuan operasi hitung penjumlahan pecahanPada siswa kelas $v$ MI Miftahul Ulum Tlogoagung Kembangbahu Lamongan. UIN Sunan Ampel Surabaya.

Syukur, M. (2018). Dasar-Dasar Teori Sosiologi. PT. Rajagrafindo Persada.

Upe, A. (2016). Metode Penelitian Sosial: Filosofi dan Desain Praktis. Kendari: Literacy Institute.

Wibowo, H. M. J. (2018). Keefektifan Model Pembelajaran Contextual Teaching And Learning Dan Problem Solving Terhadap Hasil Belajar Matematika Siswa Kelas IV SDN Gugus Dewi Sartika Kecamatan Ungaran Barat. Universitas Negeri Semarang.

Yahya, Y. (2019). Pendekatan Contextual Teaching And Learning (CTL) dalam meningkatkan hasil belajar siswa kelas IX pada mata pelajaran fiqih materi jual beli di Madrasah Tsanawiyah Mardiah Islamiyah Panyabungan Kabupaten Mandailing Natal. IAIN Padangsidimpuan. 